\title{
Suriye Ekmeği Üretimi, Üretim Hataları ve Önleme Yolları
}

\author{
Mehmet KÖTEN ${ }^{1} *$, Mustafa SATOUF ${ }^{1}$, Halil EKici ${ }^{1}$ \\ ${ }^{1}$ Kilis 7 Aralık Üniversitesi, Mühendislik-Mimarlık Fakültesi, Gıda Mühendisliği Bölümü, Kilis-TÜRKiYE \\ [ORCID ID: http://orcid.org/0000-0002-8232-8610 (M. KÖTEN), 0000-0002-8349-4899 (M. SATOUF), 0000-0002- \\ 8750-5591 (H. EKiCi)] \\ *Sorumlu yazar: mehmetkoten@gmail.com
}

\begin{abstract}
Öz
Dünyada insanların en önemli enerji kaynağı olan ekmek, Türk ve Arap kültürlerinde kutsal sayılmaktadır. Suriye'de yaşanan iç savaştan kaçan Suriyelilerin yerleştikleri bölgelerde kendi ekmeğini üretmeye başlaması yeni bir sektörün doğmasına neden olmuştur. Suriye ekmeği (Arap ekmeği), Ortadoğu'nun birçok ülkesinde tüketilen ince ve kolaylıkla dürüm yapılabilir yumuşaklıkta bir ekmektir. Ülkemizde de üretilen Suriye ekmeklerinin kalitesinin istenen düzeyde olmadığı bilinmektedir. Bu çalışmada, Türkiye'de üretimi ve tüketimi oldukça yüksek düzeylere ulaşan ancak hala bazı önemli kalite problemleri olan Suriye ekmeklerinin üretimi, üretim hataları ve bu hataları önleme yolları tartışımıştır.
\end{abstract}

Anahtar Kelimeler: Ekmek, Suriye ekmeği, Ekmek hataları

\section{The Syrian Bread Production, Production Defects and Prevention Methods}

\begin{abstract}
Being as the most important dietary energy source in the world, bread is considered sacred in Turkish and Arabic cultures. The beginning of bread making by syrian people who fled from Syrian civil war to the neighboring countries of Syria, lead to a new sector to emerge in those countries. The Syrian bread (Arabic bread) is consumed in many countries in the Middle East and it has a soft texture that makes it suitable for using it as a wrap bread. It has been observed that the Syrian breads those are produced in our country do not have the desired quality level which are consumed on a large scale. In this study, the production of Syrian bread, where as its production and consumption levels reached to a remarkable level in Turkey but it has significant quality problems, production defects and prevention methods for these defects have been discussed.
\end{abstract}

Key Words: Bread, Syrian bread, Bread defects

\section{Giriş}

Halk kültürü içerisinde önemli bir yere sahip olan yemek kültürü üzerinde, bireylerin ihtiyaçlarının, beslenme alışkanlıklarının, dini düşüncesinin, hayat tarzlarının, sosyoekonomik durumlarının etkisi olmakla birlikte en fazla yaşadığı coğrafyanın etkisi olmaktadır (Oğuz, 2002).
İnsanların yaşadığı fiziki ve kültürel coğrafi ortam, yemek kültürünü etkilemekle beraber, yaşam şeklindeki değişim ve dönüşüm yemek kültürünün de değişmesine sebep olmaktadır (Beşirli, 2010).

Suriye'de 15 Mart 2011 tarihinde ortaya çıkan iç savaş ve akabindeki istikrarsızlık, Suriyelilerin zorunlu göçe maruz kalmalarına neden olmuştur. Yüz binlerce kişi işini 
kaybetmiştir. Ülkesini terk eden iş adamları ve esnaf da gittikleri ülkelerde sıfırdan başlamak zorunda kalmışlardır. Bu göçten en çok etkilenen ülkelerin başında da Türkiye gelmektedir.

Suriye'de yaşanan iç savaştan kaçan Suriyelilerin yerleştikleri bölgelerde kendi ekmeğini üretmeye başlaması yeni bir sektörün doğmasına neden olmuştur. Arap lavaşı olarak da isimlendirilen Suriye ekmeği ambalaj içerisinde $5^{\prime} \mathrm{li}, 8^{\prime} \mathrm{li}$ veya $10^{\prime}$ lu olarak satılmaktadır. Ekmeğin ambalajında Arapça yazılar yer alırken, Suriye ekmeğinin satıldığı işyeri sahipleri, ekmeğin en az Suriyeliler kadar Türkler tarafından da tüketildiğini belirtmektedirler. Suriye ekmeği (Arap ekmeği), Ortadoğu'nun birçok ülkesinde tüketilen ince ve kolaylıkla dürüm yapılabilir yumuşaklıkta bir ekmektir.

Insanların beslenmesi ve yemek kültürü içerisinde ekmeğin önemli bir yeri bulunmaktadır. Ülkelerin gelişmişlik düzeyine ve bireylerin sosyo-ekonomik yapısına bağı olarak tüketilen ekmek miktarı değişiklik gösterse de günlük alınan enerjinin önemli bir bölümü ekmekten sağlanmaktadır (Baysal ve Över, 1994) .

Dünyada insanların en önemli enerji kaynağı olan ekmek, Türk ve Arap kültürlerinde (Sümer'lerden gelen kültür) kutsal sayılmaktadır. Ülkemizde üretilen Suriye ekmeklerinin kalitesinin istenen düzeyde olmadığı bilinmektedir. Ekmek kalitesinin istenen düzeyde olmaması raf örünün kısalmasına ve kısa zamanda bayatlamasına neden olmaktadır. Bu da bir başka problemin, ekmek israfının en önemli nedeni sayılmaktadır.

Bu çalışmada, Türkiye'de üretimi ve tüketimi oldukça yüksek düzeylere ulaşan ancak hala bazı önemli kalite problemleri olan Suriye ekmeklerinin üretimi, üretim hataları ve bu hataları önleme yolları tartışılmıştır. Çalışmada nitel araştırma yöntemlerinden gözlemle veri toplama ve yazılı kaynakların (makaleler, kitaplar vb) incelenmesi tekniğinden yararlanılmıştır.

\section{Suriye Ekmeği}

Tanım

Şekli yuvarlak, 20-35 cm çapında, iki katlı, kalınlığı 2-3 mm olan düz bir ekmektir. Bu ekmek genel olarak arasına çeşitli gıdalar konularak dürüm şeklinde tüketilmektedir (Satouf, 2012; Williams ve ark., 1988).

Dünyada 60'tan fazla düz ekmek çeşidi vardır ve Suriye ekmeği bunlardan biridir. Suriye ekmeği iki gruba ayrılabilir:

a) Tek katı: Oldukça ince, oval şekilli, çapı iki katlı ekmeklere göre daha yüksek, sac, tandır veya taş fırınlarda suyunun büyük bir kısmını kaybedinceye kadar pişirilen ekmeklerdir. Ülkelere göre ekmek tipleri farklı olabilmektedir (yufka, pide, mefrud).

b) iki katlı: En çok Suriye, Lübnan, Filistin, Mısır, Avustralya ve Körfez ülkelerinde üretilmektedir. Ülkelere göre isimler de farklı olmaktadır (Kmaj, balady, arabi, shami vb).

Tüketici taleplerine göre Suriye ekmeğinin kalınlığı ve rengi değişebilmektedir. Bazı tüketiciler ince ekmek talep ederken, bazıları kalın ekmek tercih etmektedir. Renk olarak beyaz ya da daha esmer renkte ekmekler üretilebilmektedir. Beyaz ekmekler için \%7072 randımanlı unlar (kül değeri yaklaşık \% 0,55-0,65 arasındadır) kullanılırken, daha esmer ekmekler için \%82-95 (kül değeri yaklaşık \% 0,65-0,95 arasındadır) randımanlı unlar kullanılmaktadır. Kullanılan unların protein içeriği de optimum \% 12 civarındadır (Al-Dmoor, 2012; Gocmen ve ark., 2009; Köten ve Ünsal, 2007; Coşkuner ve ark., 
1999; Qarooni ve ark., 1992; Faridi ve Rubenthaler, 1983).

\section{Kalite Özellikleri}

Ekmek kalitesinin değerlendirilmesinde ekmeğin dış görünüşü ve iç yapısına ait birtakım özellikler esas alınmaktadır. Bu özelliklere dair değerler belirli limitler arasına girmediği takdirde üründe birtakım hatalar var demektir.

\section{Dış görünüş̧ özellikleri}

Boyut, şekil, pürüzsüzlük, kabuk rengi, üst ve alt yüzey görünüşü, yüzeydeki benekli yapı, ekmek kalınlığı gibi özelliklerdir. Dış görünüş tüketici açısından en önemli kalite kriteridir. Albeniyi etkileyen en önemli özellikten bir tanesidir. Bu nedenle üretimde ekmek dış görünüşünün en iyi düzeyde olması gerekmektedir. Dış görünüş ekmek kalitesi hakkında ilk izlenimi kazandırmaktadır (Özkaya ve Özkaya, 1993).

\section{iç görünüş özellikleri}

íki katlı olması yani katmanların birbirinden kolaylıkla ayrılması, ekmeğin iki katmanının birbiriyle aynı özellikte olması (ağırlık, kalınlık vb), ekmek içinin ince gözenekli yapıda olması, ekmek içi renginin beyaz ile krem rengi arasında olması ve ekmek içi tekstürü gibi özellikler dikkate alınmaktadır.

\section{Üretim kalitesi}

Ekmeğin kolaylıkla parçalanabilme özelliği (kolay parçalanması istenmez ve dürüm yapılıp (bükme) tekrar açıldığında parçalanmaması istenir), bayatlama (tazelik), tat, koku, ağız hissi gibi özellikler ön planda tutulmaktadır (Al-Eid ve ark., 2010; Quail, 1996; Williams ve ark., 1988).

\section{Suriye Ekmeği Üretiminde Kullanılan Hammaddeler}

Un

Kullanılan un genellikle sert ekmeklik buğdaylardan elde edilmektedir. Protein oranı yaklaşık \%10-13 arasındadır. Unun elde edildiği buğdayın sertlik derecesi 20 den azdır (PSI<20). Düşme sayısı 250'den fazladır (optimum 300-350). Zedelenmiş nişasta \%6-9 arasındadır. Farinografta belirlenen su tutma kapasitesi (su absorpsiyon oranı) \%55-65 arasındadır. Gelişme süresi 2-5 dakikadır. Suriye'de \%80-82 randımanlı unlar kullanılmaktadır (Satouf, 2012; Qarooni, 1996; Qarooni ve ark., 1993; Quail ve ark., 1991a).

\section{Su}

Ekmek yapımındaki en önemli bileşenlerdendir. Kullanılan suyun miktar ve bileşimi hamurun kalitesine doğrudan etki etmektedir.

Ekmek hamurunda kullanılacak su;

- İçilebilir nitelikte olmalıdır,

- Temiz olmalıdır,

- Mikrobiyolojik açıdan temiz olmalıdır,

- Orta sertlikte (50-100 ppm $\mathrm{CaCO}_{3}$ ) olmalıdır,

- Yaklaşık \%53 \pm 2 civarındadır (Anonim, 2012).

Tuz

Pratikte tuz katılmış hamurların kolay işlendiği bilinmektedir. Tuzun hamur içinde çeşitli fonksiyonları olmakla birlikte en önemli etkisi lezzete yönelik olmaktadır. Genel tüketici yapısı tuzsuz ekmeği tercih etmemektedir (Anonim, 2012). 
Tuz, verdiği lezzetin yanı sıra hamurun fiziksel özelliklerini de aşağıdaki şekillerde geliştirir:

- Gluteni güçlendirerek yumuşamayı önler, mayanın çalışması üzerinde etkilidir,

- Farklı mikroorganizmaların fermantasyonunu da kontrol ettiğinden istenmeyen asitlik ve tadın oluşmasını engeller,

- Tuzsuz ekmeklerin küflenme süreleri daha kısa olur (Anonim, 2012).

Tuzun hamur üzerindeki etkileri şunlardır

- Glutenin direnç ve elastikiyetini arttırır,

- Hamur stabilitesini arttırır,

- Hamuru kolay işlenir hale getirir,

- Düzgün ve ince gözenekli içyapı sağlar,

- Renk verir,

- Raf ömrünü uzatır (Anonim, 2012).

Maya

Canlı bir organizma olan maya, fermantasyonu sağlayan esas unsurdur. Fermantasyon sırasında meydana gelen karbondioksit, hamur içerisinde birikerek ekmeğin kabarmasını; meydana gelen alkoller, aldehitler, ketonlar ve organik asitler de ekmeğin iştah açıcı karakteristik tat ve aroma kazanmasını sağlar. Ayrıca, mayanın diğer bir rolü hamurun fiziksel özelliklerini değiştirmesidir. Böylece glutenin elastikiyeti artmakta ve hamur kütlesi içinde biriken karbondioksit gazı basıncına daha iyi dayanan ve onu tutan bir yapı kazanmaktadır (Akın ve Engin, 2014; Anonim, 2012; Kalkışım ve ark., 2012; Pyler ve Gorton, 2009).

\section{Katkı Maddeleri}

Tatlandırıcı olarak kullanılan şekerler; fermantasyon hızını, gaz oluşumunu ve hamurun yapısını etkiler. Kabuk rengi ve pişirme sırasında aroma maddeleri ile aroma oluşumuna katkıda bulunur. Özellikle mayanın karbondioksit ve alkol oluşturmasında kaynak görevi yapar. Fermantasyon amacıyla tavsiye edilen miktar \% 0.2-0.6 arasındadır. Çok sık rastlanmamakla birlikte bazı işletmelerde hamura çok az oranda sıvı bitkisel yağ (un ağırlığı üzerinden yaklaşık $\% \quad 0.5$ ) da eklenmektedir.

Genel olarak:

- Fermentasyon için mayaya besi kaynağı oluşturur,

- Ekmeğin kabuk rengine ve lezzetine katkıda bulunur,

- $\quad$ Ekmeğe yumuşaklık vererek saklama kalitesini geliştirir,

- Yüksek miktarda kullanıldığında ekmeğin çabuk renk almasını sağlar (Satouf, 2012; El-Khoury, 1999).

\section{Suriye Ekmeği Üretim Aşamaları}

\section{a) Yoğurma}

Tüm hamur bileşenlerinin karıştırılması sürecidir. Yoğurucuya ilk un konur ve 2-3 dakika havalandırıması için karıştırılır. Daha sonra kuru hammaddeler eklenir karıştırılır. Yaklaşık \% 53 oranında su eklenir. Maya un bazında \%2 oranında kullanılır (yaş maya), tuz un bazında \%1-1,5 arasında eklenir (kullanılan suyun bir kısmında çözünerek eklenir). Un kalitesi ve sıcaklığa bağlı olarak yoğurma süresi 10 ile 20 dakika arasında değişmektedir. Yoğurma işlemi hamur kalitesini önemli derecede etkilemektedir. Uygun yoğurma işlemi kabarmayı sağlayacak düzgün protein (gluten) ağının oluşmasına ve bu ağın hamurda gaz tutma kapasitesinin yüksek olması anlamına gelmektedir. Ayrıca 
şekil verme açısından da yoğurma işlemi önem taşımaktadır (Satouf, 2012; Gocmen ve ark., 2009; Qarooni, 1996; William ve ark., 1988).

\section{b) Birinci Fermantasyon}

$\mathrm{Bu}$ işlemin amacı hamurdaki bileşiklerin (karbonhidrat ve proteinler) daha farklı ürünlere (şeker, alkol, karbondioksit, asitler gibi) dönüşümlerini sağlamaktır. Fermantasyonla hem gluten ağı hem de hamurun elastikiyeti gelişmekte ve böylece karbondioksit daha etkin bir şekilde tutulmaktadır.

Yoğrulan hamur özel fermantasyon tanklarına aktarılır. Bu tanklar $25-35^{\circ} \mathrm{C}^{\prime}$ lik sıcak ortamda ve üzerileri kapatılarak (naylon ya da bez ile) yaz aylarında 30 dakika, kış aylarında 45 dakika fermantasyon gerçekleştirilir (Satouf, 2012; Gocmen ve ark., 2009; Qarooni, 1996; William ve ark., 1988).

\section{c) Kesme ve Şekillendirme}

Küçük kapasiteli fırınlarda elle, yüksek kapasiteli fabrikalarda otomatik makinelerle hamur kesme işlemi gerçekleştirilmektedir. Mümkün olduğunca kesilen hamurların yuvarlak olması istenir. Kesilen hamurların üzerine banta ve şekillendirme silindirlerine yapışmaması için bir miktar un (az miktarda) serpilir. Serpilen unun fazlası da alınmalıdır. İstenen ekmek ağırlığına göre hamur ağırlığı ayarlanarak kesme işlemi yapılmaktadır. Kesilen yuvarlak hamurlar yaklaşık 5 dakika dinlendirilir (kesmeyle zarar gören gluten ağı tekrar toplanır ve gazlar tekrar muhafaza edilmiş olur). Dinlendirilen hamurlar şekillendirilmek üzere yüzeyi teflon ya da paslanmaz çelik ya da kromdan yapılmış silindirlere gönderilir. Bu silindirlerin aralığı (iki silindir arası uzaklık) istenilen hamur kalınlığına göre ayarlanmaktadır. Şekillendirme iki aşamada gerçekleştirilmektedir. Illk silindirlerde elips şekline gelen hamurlar ikinci silindirlere tam tersi yönünde girerek yuvarlak şeklini almaktadır (Satouf, 2012; Gocmen ve ark., 2009; Qarooni, 1996; William ve ark., 1988).

\section{d) Son Fermantasyon}

Şekillendirilen hamurlar kumaştan (keten) yapılmış bantlar üzerinde etrafı kapalı tünele (20-25 derece sıcaklık ve nem \%75-80 olan) girerek yaklaşık 10-15 dakika fermantasyona bırakılmaktadır. Bu sırada nem miktarı eğer fazla ise kabinin kapakları açılarak nem düzeyi azaltılmaktadır. Nem az ise hamur yüzeyi kuruyacağından nem kontrolü dikkatli bir şekilde yapılmalıdır (Satouf, 2012; Gocmen ve ark., 2009; Qarooni, 1996; William ve ark., 1988).

\section{e) Pişirme}

Fermantasyon kabininden çıkan hamurlar metal bantlara aktarılarak 550-650 ㅇ' deki pişirme tüneline (fırın) girmektedir. Fırın sıcaklığı yüksek olduğundan hamurlar aniden şişerek iki katlı formunu alarak pişmiş bir şekilde fırını terk etmektedir. Eğer fırın çıkışı ekmekler tam pişmemiş ise (beyaz ise) fırın sıcaklığı artırılmakta ya da bant hızı azaltılmaktadır. Fırına giren şekillendirilmiş hamur sayısı önem arz etmektedir. Yanmış ekmek elde edilmek istenmiyorsa şekillendirilmiş hamurlar birbirine en fazla 5$10 \mathrm{~cm}$ uzaklıkta olmalıdır. Fırında kullanılan yakıt genellikle mazottur ve direkt bir yanma sağlanarak kullanılmaktadır (Şekil 1). Pişirme süresi genellikle 10-40 saniye optimum 25 saniyedir. Son fermantasyonda gazlardan dolayı hamurda oluşan gözenekli yapı, fırındaki ani sıcaklıkla karşılaştığında daha da büyüyerek iki katlı bir şekil kazanılmaktadır 
(Satouf, 2012; Gocmen ve ark., 2009; Qarooni, 1996; William ve ark., 1988).

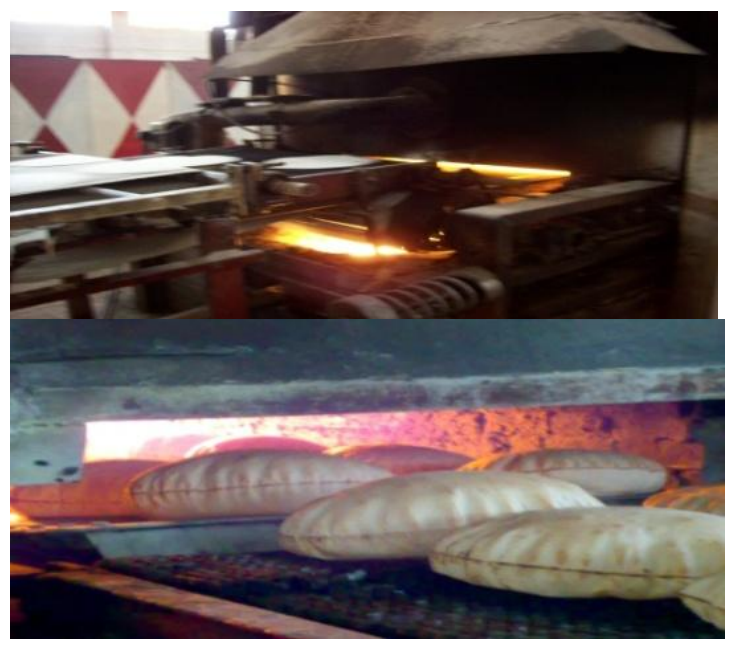

Şekil 1. Ekmeklerin fırına girişi ve çıkışı

Figure 1. Entrance and exit of breads in the oven

\section{f) Soğutma}

Pişen ekmeklerin sıcaklığı $18-25^{\circ} C^{\prime}$ ye düşürülmektedir. Ekmekler etrafı açık metal ve delikli yatay bantlar (daha fazla alan kaplayan sistem) üzerinde normal ortam koşullarında soğutmaya bırakılır. Dikey batı soğutma sistemlerinde (daha az alan kaplayan sistem) alttan vantilizasyon sistemi, üstten havayı çeken bir sistemle soğutma işlemi gerçekleştirilmektedir. Soğutma süresi yaklaşık 10 dakika sürmektedir. Soğutma işlemi tam olarak gerçekleştirilmezse;

- su buharı ekmek içinde kalmakta,

- ekmek katmanları birbirine yapışacağından birbirinden kolaylıkla ayrılamamaktadır. Bu durum tüketici tarafından tercih edilmemektedir.

- ekmek çabuk bozulmaya yatkın bir hal almaktadır. Ayrıca ekmek ağırlığı artmaktadır (Satouf, 2012; Gocmen ve ark., 2009; Qarooni, 1996; William ve ark., 1988).

g) Ambalajlama
Soğuyan ekmeklerden yaklaşık 9-10 adeti üst üste olacak şekilde (1 ya da $1.5 \mathrm{~kg}$ ) polietilen veya poliamid poşetlere konularak ambalajlanmaktadır. Ambalaj üzerinde etiket bilgileri de yer almaktadır (Satouf, 2012; Gocmen ve ark., 2009; Qarooni, 1996; William ve ark., 1988).

\section{Üretim Hataları ve Önleme Yolları}

Suriye ekmeğinde meydana gelen hataların nedenleri genel olarak şunlardır:

- Hammadde kalitesinin düşük olması (un, su, tuz, maya vb)

- Teknik nedenler (pişirme yöntemi, proses aşamalarında meydana gelen hatalar-yoğurma sırasında yapılan hatalar, pişirmedeki hatalar, vb)

- Üretimde görev alan kişilerin uzmanlık bilgisindeki yetersizlikler.

$\mathrm{Bu}$ nedenler ekmekte dış ve iç görünüş özelliklerinde hatalar olması anlamına gelmektedir (Satouf, 2012).

Ekmek Boyutu: Tüketicilerin istekleri doğrultusunda ayarlanmaktadır. İsrafı önlemek adına tüketicilerin tercih ettiği miktar ve boyutta üretim gerçekleştirilmektedir. Üretimde ekmeklerin boyutları birbirine eşit olmalıdır. Ambalajlama açısından boyut önemli bir faktördür. Çünkü otomatik ambalajlamalarda ekmeklerin boyutlarının eşit olması istenir. Bu durumda kontrol çok önemlidir (Anonim, 2016; Amr ve Ajo, 2005).

\section{Eğer üretilen ekmek çok küçükse;}

- Hamur inceltme silindirlerinin ayarı tam doğru değildir. Silindirler arası mesafe çok fazladır.

- Ekmek hamuru ağırlığı düşüktür. 
- Hamur kalitesini etkileyen protein kalitesinin yüksek oluşu yani hamur elastikiyetinin fazla olmasıdır. Bu durumda protein kalitesi düşük un (farinografta hamur stabilitesi-2 dakika ve altı- düşük olan un) ile paçal yapılabilir ya da hamur fermantasyon süresi uzatılabilir.

\section{Eğer üretilen ekmek çok büyükse;}

- Hamur inceltme silindirlerinin ayarı doğru yapılmamıştır. Silindirler arası mesafe çok azdır.

- Hamur ağırlığı fazla tartılmıştır.

- Kullanılan un zayıf kalitededir. Yani unun protein kalitesi düşüktür. Bu durumda protein kalitesi yüksek unla (farinografta hamur stabilitesi- 5 dakika ve üstü- yüksek olan un) paçal yapılabilir ya da vital gluten katılabilir ya da askorbik asit katılabilir.

\section{Şekil}

Suriye ekmeğinde tam yuvarlak, yırtılmamış, kenarları oldukça düz bir yapı istenir. Eğer bu özelliklerde hatalar var ise nedenleri şunlardır:

- Kullanılan un kalitesi (unun protein kalitesinin düşük ya da yüksek olması)

- Inceltme silindirlerinin ayarının tam yapılamaması

- Hamur eğer çok kuvvetli yani sertse;

a. Yoğurma süresi uzatılabilir

b. illk fermantasyon süresi uzatılabilir

c. Una eklenen su miktarı artırılabilir

d. Katkı maddeleri kullanılabilir (hamur zayiflatıcı) (Anonim, 2016; Amr ve Ajo, 2005)
Ekmek kabuğunun (yüzeyinin) pürüzsüzlüğü

Ekmek yüzeyinin düzgünlüğünü etkileyen en önemli faktör şekillendirme silindiri üzerinde yer alan temizleme (kazıyıcı) bıçağında hamur parçacıklarının kalmasıdır yani bıçağın kirlenmesi ve ayarının tam yapılmamış olmasıdır (Satouf, 2012).

Ekmekte oluşan çatlaklıklar (yırtıklar): Pişirme sırasında oluşan su buhar basıncının yüksek olması ekmeğin kabuğunda yırtılmalara neden olmaktadır. Bu durum ürün albenisinde azalma yaratmaktadır. Çiğneme kalitesinde düşüşe neden olmaktadır. Ancak alt yüzeyde oluşan çatlaklıklar ürün albenisinde olumsuzluk yaratmamaktadır (Satouf, 2012; Amr ve Ajo, 2005).

\section{Ekmek yüzeyinde oluşan catlaklıklar}

$\mathrm{Bu}$ durumun oluşmasındaki nedenler şunlardır:

- Ekmek kabuğunun kalın olması ve kuru olması

- Son fermantasyon süresinin fazla olması (süre uzarsa şekil verilen hamur yüzeyi kurumaktadır)

- Fırın sıcaklığının homojen olmaması ve fırın içindeki nem düzeyinin (buhar injeksiyonu yok ama nem hamurdan kaynaklanmaktadır) çok düşük olması (fırına ilk giriş tarafındaki sıcaklığın ve nemin düşük olması). Bunu önlemek için fırına giren ekmeklerin arasındaki mesafenin azaltılması gerekir. Böylece fırın içine giren ekmek sayısı artacağından nem miktarı da artmış olacak ve çatlama önlenmiş olacaktır. Sürekli sistemlerde bu sorun görülmezken, kesikli sistemlerde pişirmenin ilk dakikalarında olmaktadır. 


\section{Ekmek kenarında olușan çatlaklıklar}

Bu çatlaklıklar tüketici tercihini olumsuz etkilemektedir. Bu çatlaklıklar ekmek katmanlarının kolaylıkla açılmasına neden olmaktadır. Nedenleri:

- Hamur şekillendirilmesi tam yuvarlak yapılmamıştır. Tam yuvarlak olarak şekillendirme çatlaklık oluşumunu engelleyecektir.

- Son fermantasyonda nem kaybından dolayı ekmek yüzeyinde kuruma olmuştur. Nem kaynını en aza indirgemek çatlaklık oluşumunu engelleyecektir.

- Pişirme iyi yapılmamıştır. Homojen bir üst yüzey pişirmesi gerçekleştirilmemiştir.

- Fırından çıkan ekmeklerin soğutulması çok kısa ya da çok uzun sürede yapılmıştır. Eğer çok kısa süre soğutma yapılmışsa ekmek içinde kalan buhar paketleme sırasındaki baskıdan dolayı ekmeğin yırtılmasına neden olacaktır. Çok uzun süre soğutmada ise ekmek yüzeyi kuruyacağından yine çatlaklıklar meydana gelecektir.

\section{Alt yüzeyde oluşan çatlaklıklar:}

- Ekmek taşıyıcı bantların yapıldığı malzemenin özellikleri

- Eğer taşıyıcı bant metal ise bu metalin sıcaklığının fırın sıcaklığından yüksek olması

- Bantlar parça parça monte edilmiş ise ekmek iki bantın birleştiği noktaya konulmuşsa iki bant arasındaki sıcaklığın düşük olmasından dolayı ekmek altı çatlayacaktır.
- Un kalitesinin çok yüksek olması da çatlaklık oluşumuna neden olabilmektedir.

Renk

Ekmek rengi tüketici talebinde en etkili faktörlerdendir. Bazı tüketiciler beyaz renkte ekmek talep ederken, bazı tüketiciler daha koyu renk tercih edebilmektedir.

\section{Ekmek rengi açık ise:}

- Fırın sıcaklığı ve pişirme süresi (fırın sıcaklığı ne kadar düşük ve pişirme süresi ne kadar kısa ise ekmek rengi o derecede açık olmaktadır)

- Un kalitesi (protein ve şeker miktarının az olmasından dolayı esmerleşme reaksiyonu az olacaktır)

Açık renk oluşumunu önlemek için; fırın sıcaklı̆ğ ve süresi kontrol edilmelidir, un kalitesi yüksek yani protein miktarı yüksek un kullanılmalıdır.

\section{Ekmek rengi koyu ise:}

- Fırın sıcaklığı ve pişirme süresi (fırın sıcaklığı ne kadar yüksek ve pişirme süresi ne kadar uzun ise ekmek rengi o derecede açık olmaktadır)

- Un kalitesi ( protein ve şeker miktarının yüksek olmasından dolayı esmerleşme reaksiyonu fazla olacaktır)

- $\quad$ Undaki kül, zedelenmiş nişasta ve alfa amilaz miktarı fazla ise kabuk rengi koyu olmaktadır.

Koyu renk için ve tat için una bazen süttozu veya malt unu eklenebilmektedir.

\section{Ekmek rengi homojensizliği:}

- Fırın sıcaklığı homojen değildir. Bu anlamda fırın tasarımı oldukça önemlidir. 


\section{Ekmek yüzeyinde kabarcık oluşumu}

Tercih edilmeyen bir durumdur. Nedenleri:

- Son fermantasyon süresi ve nem oranı (süre uzun ve nem miktarı fazla ise bu fazla nem ekmek yüzeyinde değişik noktalarda birikeceğinden pişirme sırasında bu noktalarda kabarmalar olacaktır). Bu durumu önlemek için fermantasyon kabinlerinde nem kontrolü çok iyi yapılmalıdır. Gerekirse vantilasyon sistemi kullanılmalıdır.

\section{Ekmek yüzeyinden farklı renkte noktacıkların} oluşumu

- Fermantasyonda rol oynayan ekmek mayasının miktarının az, kalitesinin düşük olması.

- Son fermantasyon süresinin kısa olması, sıcaklığının düşük olması.

- Hamura eklenen su miktarı az ya da çok ise.

- Şekillendirici silindir üzerindeki kazıyıcı bıçağın temiz olmaması (bıçak üzerinde kalan hamur parçacıklarının şekillendirilmiş hamur üzerine düşmesi)

- Şekillendirme sistemi içinde hamurun silindire yapışmasını engellemek için silindir üzerine püskürtülen un parçacıklarının ekmek hamuru yüzeyinde kalması (Anonim, 2016).

iç Özellikler

Cep olușumu

Suriye ekmeğinin en önemli özelliklerinden birisidir. Bu özellik pişirme sırasında oluşan bir özelliktir. İki katlı ekmek olma özelliğidir. Düzgün bir cep oluşması katmanların birbirinden kolaylıkla ayrılması anlamına gelmektedir. Cep oluşumu gerçekleşmiyorsa nedenleri şunlardır (Al-Eid ve ark., 2015; Satouf, 2012):

- Son fermantasyon sırasında oluşması gereken ekmek içi gözeneklerinin homojen oluşmaması.

- Un kalitesi yani gluten kalitesi düşükse hamurun gaz tutma kapasitesi düşmektedir.

- Fırın içi sıcaklık ile taban sıcaklığı (taşıyıcı bant sıcaklığı) arasındaki fark yüksekse.

- Soğutma işlemi tam olarak yapılmayıp fırından çıkan ekmek hemen üst üste paketlenirse.

- Pişme süresi kısa tutulmuşsa ekmek içerisinde nem fazlalığı olacağından iki katmanın birbirine yapışması söz konusu olacaktır.

- Şekillendirmede hamur kalın bırakılmıştır. Pişme süresi uygun olsa da hamur kalın olduğundan cep oluşumu gerçekleşmeyecektir.

- Şekillendirmede hamur çok ince açılmışsa da cep oluşumu gerçekleşmeyecek ve hatta ekmek yanacaktır.

\section{Ekmek içi tekstür}

Un kalitesi (protein miktar ve kalitesi) düşükse unun su tutma kapasitesi düşük olacağından ekmek pişme sonrasında daha kuru olacaktır. Unun zedelenmiş nişasta oranı düşükse yine su tutma kapasitesi az olacağından kuru ekmek elde edilecektir. Pişme süresi hamurun kalınlığına bağlı olarak ayarlanmalıdır. Eğer hamur kalınsa daha uzun bir pişme süresi, hamur ince ise daha kısa bir pişirme süresi uygulanmalıdır. Şekillendirmede hamur kalın bırakılmıştır. Pişme süresi uygun olsa da hamur kalın 
olduğundan

cep

oluşumu

gerçekleşmeyecektir. Şekillendirmede hamur çok ince açılmışsa da cep oluşumu gerçekleşmeyecek ve hatta ekmek yanacaktır.

Ekmek içi homojen değilse;

- Hamur miktarı az tartılmıştır

- Hamur çok kuvvetlidir

- Son fermantasyon çok uzun süre gerçekleştirilmiştir.

- Un kalitesi (protein miktar ve kalitesi) düşükse ekmek içi sıkı ve hamurumsu bir hal almaktadır. Bu nedenle hem tat hem de çiğneme özelliği düşük olacaktır.

- Eğer pişme sonrası gerçekleştirilen soğutma prosesi tam olarak gerçekleştirilmezse ekmek tekstürü istenmeyen hal alacaktır. Soğutma süresi kısa tutulursa ekmek yüzeyi soğumasına karşın ekmek içi tam olarak soğumayacak ve bu durum daha sonra ekmeğin oldukça yumuşak ve nemli olmasına neden olacaktır. Ekmeğin iki katlı olma özelliği de kaybolacaktır. Soğutma süresi çok uzun tutulursa bu sefer de ekmek nem oranı çok düşük olacağından ekmeğin kuru bir hal alıp, bükülme (katlanma) özelliği çok düşük olacağından çabuk parçalanması söz konusu olacaktır.

\section{Ekmek içi rengi}

Randımanı yüksek undan yapılan ekmeklerin iç rengi daha esmer olurken, randımanı düşük unlardan yapılan ekmeklerin iç rengi arzu edilir beyaz renkte olmaktadır (Anonim, 2012; Özkaya ve Özkaya, 1993).

\section{Taşıma (nakliye) Kalitesi}

Tüketici ekmeği fırından çıktığı şekilde ve özelliklerde istemektedir. Bu nedenle taşıma sırasında şekil bozulmayacak şekilde taşıma yapılmalıdır. Taşımanın uygun bir şekilde yapılması şunlara bağlıdır:

- Öncelikle ekmekler ambalajlamadan önce iyi soğutulmalıdır.

- 1-1.5 kg olacak şekilde poşetlere ambalajlana ekmekler taşıma kasalarına en fazla 3-4 paket konacak şekilde istiflenmelidir. Eğer fazla sayıda poşet kasalara konursa ekmekler iki katlı özelliğini kaybedecek ve tüketici isteklerini karşılayamayacak duruma gelecektir.

- Eğer pişme sonrası gerçekleştirilen soğutma prosesi tam olarak gerçekleştirilmezse ekmek tekstürü istenmeyen hal alacaktır. Soğutma süresi kısa tutulursa ekmek yüzeyi soğumasına karşın ekmek içi tam olarak soğumayacak ve bu durum daha sonra ekmeğin oldukça yumuşak ve nemli olmasına neden olacaktır. Ekmeğin iki katlı olma özelliği de kaybolacaktır.

- Soğutma süresi çok uzun tutulursa bu sefer de ekmek nem oranı çok düşük olacağından ekmeğin kuru bir hal alıp, bükülme (katlanma) özelliği çok düşük olacağından çabuk parçalanması söz konusu olacaktır.

Hem tekstürü hem de taşıma kalitesine etkili olan en önemli unsur ekmeğin nemidir. Nemden kaynaklana hataları azaltmak adına şunlar yapılabilir;

Una vital gluten eklenebilir ya da kalitesi yüksek un ile paçal yapılabilir. Özellikle fermantasyon aşamalarında nem kaybını önlemek adına gerekli tedbirler alınmalıdır. 
Yani ortam sıcaklığı ve nemi kontrol altında tutulmalıdır. Mesela; fermantasyon sırasında hamurun üzeri bir örtüyle örtülebilir. Ayrıca ortam sıcaklığı ve nemi yüksekse havalandırma yapılabilir. Tam tersi durumunda ise ortam sıcaklığı ve nemi artırılmalıdır. Fırın sıcaklığı homojen olmalıdır. Pişirme sıcaklığı ve süresi hamur kalınlığına göre ayarlanmalıdır. Pişme sonrası yapılan bir test ile ekmeğin bayatlama durumu gözlenebilmektedir. 2, 8 ve 24 saat ambalajı içerisinde oda koşullarında bekletilen ekmekler hala kolaylıkla katlanabiliyorsa tazeliği iyidir sonucuna varılmaktadır. Bayatlamayı geciktirmek adına; kullanılan unun kalitesinin yüksek, mayanın taze ve aktivitesinin standartlara uygun ve kullanılan suyun içme suyu niteliğinde olmasına dikkat edilmelidir.

\section{Tat ve Aroma}

Un randımanı tat ve aroma üzerine etki etmektedir. Randımanı yüksek olan undan yapılan ekmeklerin tadı biraz acı olabilmektedir. Bunun nedeni de randımanı yüksek unda ruşeym ve kepek varlığından dolayı yağ oranının yüksek olması ve bu yağın kolaylıkla okside olmasından kaynaklanmaktadır. Ayrıca çok uzun süre beklemiş undan yapılan ekmeklerin de tat ve aroması istenmeyen özelliklerde olabilmektedir.

Aroma bileşikleri genellikle fermantasyon sırasında oluşmaktadır. Eğer fermantasyon süreleri kısa tutulursa bu bileşikler tam olarak oluşamayacağından ekmek aroması da düşük olacaktır. Ekşi hamur kullanmak suretiyle ekmek aroması oldukça olumlu yönde artırılabilir.

Ekmek ne çok kuru ne de çok nemli olmalıdır. Tüketicide ağız hissi ekmeğin tekstürüne bağııdır. Çiğneme sırasında ekmek çok yumuşaksa hamur tadı vermektedir. Çok kuru ekmek ise çiğneme kalitesini olumsuz etkilemektedir.

Tat ve aromayı fırında kullanılan yakıtlar da etkilemektedir. Suriye ekmeği pişiriminde genellikle mazot kullanılmakta olup ilk pişirilen ekmeklerde (fırın sıcaklığı tam oluşmadığından) mazot kokusu hissedilebilmektedir. Bu durum yakıtın yakıldığı cihaza ve yakıtın safığına da bağlıdır (Satouf, 2012; Başman ve Köksel, 1999; Quail ve ark., 1991b).

\section{Kaynaklar}

Anonim, 2016. Ekmek Yapım Problemler ve Nedenleri.http://www.tekbas.com.tr/imag es/resim/ekmekhatalari.pdf (Erişim: 18.10.2016).

Anonim, 2012. Ekmek Hamuru Hazırlama. Millî Eğitim Bakanlığı, Ankara, 66s.

Akın, V., Engin, Y., 2014. Tahıl Teknolojisi I. Ders Notları.http://www.akademik.adu.edu.tr/ myo/cine/webfolders/File/ders\%20notlari /Tahil\%20Teknolojisi\%20l.pdf (Erişim tarihi: 26.10.206).

Al-Dmoor, H.M., 2012. Flat Bread: Ingredients and Fortification. Quality Assurance and Safety of Crops \& Foods, 4 (1): 2-8.

Al-Eid, S.M., Al-Hulaibi, A.A., Ghoush, M., AlShathri, A.A., 2015. Enhancing Arabic Bread Quality and Shelf Life Stability Using Bread Improvers. J Food Sci Technol,52(8): 4761- 4772

Al-Eid, S.M, Al-jasass, F., Hamad, S.H., 2010. Performance of Baker's Yeast Produced Using Date Syrup Substrate On Arabic Bread Quality. African Journal of Biotechnology Vol. 9(21): 3167-3174.

Amr, A., Ajo, R., 2005. Production of Two Types of Pocket-Forming Flat Bread by The Sponge and Dough Method. Cereal Chemistry ${ }_{2}$ 82(5): 499-503.

Arzu, B., Köksel, H., 1999. Properties and Composition of Turkish Flat Bread (Bazlama) Supplemented With Barley 
Flour and Wheat Bran. Cereal Chemistry, 76(4): 506-511.

Baysal, A., Över, N., 1994. Ekmek: Beslenme ve Sağlık Yönünden Önemi. Türk Mutfak Kültürü Üzerine Araştırmalar, Geleneksel Ekmekçilik Hamur işi Yemekler, Türk Halk Kültürünü Araştırma ve Tanıtma Vakfı Yay. No: 14, s: 40- 49, Ankara.

Beşirli, H., 2010. Yemek, Kültür ve Kimlik, Milli Folklor. Cilt: 11, Yıl:22, Sayı:87, s: 159-169.

Coşkuner, Y., Karababa, E., Ercan, R., 1999. Düz Ekmeklerin Üretim Teknolojisi. Gıda, 24(2): 89-97.

El-Khoury, A.A., 1999. Shelf-Life Extension Studies on Pita Bread. Department of Food Science and Agricultural Chemistry, Macdonald Campus Mcgill University Montreal, Quebec, Canada, Master of Science Thesis.

Faridi, H.A., Rubenthaler, G.L., 1983. Experimental Baking Techniques for Evaluating Pacific Northwest Wheat in North African Breads, Cereal Chem, 60(1): 74-79.

Gocmen, D., Inkaya, A., Aydın, E., 2009. Flat Breads. Bulgarian Journal of Agricultural Science, 15(4): 298-306.

Kalkışım, Ö., Mehmet, Ö., Bayram, O., 2012. Ekmek Yapım Teknolojisi. Sage Yayıncılık, Gümüşhane Üniversitesi, 93s, Türkiye.

Köten, M., Ünsal, S.A., 2007. Şanlıurfa Yöresine Özgü "Tırnaklı ve Açık Ekmeklerin" Geleneksel Üretim Yöntemleri. Gıda, 32 (2): 81-85.

Oğuz, B., 2002. Türkiye Halkının Kültür Kökenleri I, Giriş-Beslenme Teknikleri. Anadolu Aydınlanma Vakfı Yayınları 7, İstanbul.
Özkaya, H., Özkaya, B., 1993. Ekmek Hatalarını Önlemede Katkı Maddelerinin Rolü. Un Mamulleri Dünyası, 2 (1): 16-20.

Pyler, E.J., Gorton, L.A., 2009. Baking Science and Technology. Fourth Edition, Volume II, Formulation and Production. USA, 209p.

Quail, K.J., 1996. Arabic Bread Production. American Association of Cereal Chemists, Inc., St. Paul, Minnesota, 148p.

Quail, K.J., Mcmaster, G.J., Wootton, M.J., 1991a. Flour Quality Tests For Selected Wheat Cultivars and Their Relationship to Arabic Bread Quality. J. Sci. Food. Agric. 54: 99110.

Quail, K.J., Mcmaster, G.J., Wootton, M.J., 1991b. Flat Bread Production. Technical Paper, Food Australia 43(4): 155-157.

Qarooni, J., 1996. Flat Bread Technology. Chapman \& Hall, Dept. Bc, 115 Fifth Avenue, New York, Ny 10003.

Qarooni, J., Posner, E.S., Ponte, J.G., 1993. Production of Pita Bread With Hard White and Other U.S Wheats. Lebanese Wiss. Technol. 26(2): 93-99.

Qarooni, J., Ponte, J.G., Posner, E.S., 1992. Flat Breads of the World. Cereal Foods World 37(12): 863-865.

Satouf, M., 2012. Bread and Pastes Technology. Al-Baath University-Homs, Syria, 360p.

Williams, P.C., El-Haramein, F.J., Nelson, W., Srivastava, J.P., 1988. Evaluation of Wheat Quality for the Baking of Syrian Type TwoLayered Flat Breads. Journal of Cereal Science, 7: 195-207. 